\title{
Analysis of Production Technician Satisfaction Towards Training Service Quality by Technical Training Department PT. ABC by Using Service Quality and Importance Performance Analysis
}

\author{
Gandi Suhartinah ${ }^{1}$, Hery Hamdi Azwir ${ }^{1}$ \\ 1) Industrial Engineering Department, Faculty of Engineering, President University \\ Jl. Ki Hajar Dewantara \\ Kota Jababeka,Cikarang, Bekasi - Indonesia 17550 \\ Email: 'gandi.shrtn@aiesec.net, ${ }^{2}$ hery.azwir@president.ac.id
}

\begin{abstract}
Department of technical training is the department that responsible for training program for the entire production technician in PT.ABC. In order to constantly improve the quality of training service, a research was conducted to analyze the satisfaction of production technician towards training service quality that organized by technical training department. Production technician will determine, whether the training program has been satisfactory or not. To determine the participants' satisfaction of the quality of the training service, this research has started by using the concept of service quality and also shows a model of service quality gap. Analysis of the participants' satisfaction was measured by using the service quality in order to know the gap between actual performance and expectation performance of the training service. This research was conducted to determine the priority factor that must be done to improve the quality of the training services. This factor is determined by using importance performance analysis method and the results from this research is customer satisfaction and priority factor for improvements which consists of the hygiene of training room, training content materials, training modules and clarity of training information.
\end{abstract}

Keywords: Gap, Service Quality, Training, Expectations, Actual, Importance Performance Analysis

\section{ABSTRAK}

Departemen pelatihan teknis adalah departemen yang bertanggung jawab untuk program pelatihan bagi seluruh teknisi produksi di PT.ABC. Dalam rangka peningkatan kualitas layanan pelatihan, penelitian dilakukan untuk menganalisis kepuasan teknisi produksi terhadap kualitas layanan pelatihan yang diselenggarakan oleh departemen pelatihan teknis. Teknisi produksi akan menentukan, apakah program pelatihan sudah memuaskan atau tidak. Untuk menentukan kepuasan peserta terhadap kualitas layanan pelatihan, penelitian ini dimulai dengan menggunakan konsep kualitas layanan dan juga menunjukkan model kesenjangan kualitas layanan. Analisis kepuasan peserta diukur dengan menggunakan kualitas layanan untuk mengetahui kesenjangan antara kinerja aktual dan kinerja harapan dari layanan pelatihan. Penelitian ini dilakukan untuk menentukan faktor prioritas yang harus dilakukan untuk meningkatkan kualitas layanan pelatihan. Faktor ini ditentukan dengan menggunakan metode analisis kinerja yang penting dan hasil dari penelitian ini adalah kepuasan pelanggan dan faktor prioritas untuk perbaikan yang terdiri dari kebersihan ruang pelatihan, materi pelatihan, modul pelatihan dan kejelasan informasi pelatihan.

Kata Kunci: Gap, Service Quality, Training, Expectations, Actual, Importance Performance Analysis

\section{Introduction}

Technical Training Department is the department which delivers the training service to all production technicians in the PT. ABC and responsible for carrying out the activities of coaching and other activities related to mental development, skills and knowledge of production technician. However, the training services get dissatisfactory responses from the production technician in the production area, secondary processing PT. ABC. This is proven by the results of direct observation of Module Development Team conducted in production area, secondary processing PT. ABC. During the module development program conducted in production area of secondary processing, the 
production technician gives their feedback on training feedback form, and most of them are dissatisfied with the training service quality that has been given by technical training department, this is also proved by the declining percentage of training participants in 2015 from the previous year of $6 \%$. In 2014, the percentage of training participants is $95 \%$ while in 2015 the percentage of training participants is $89 \%$. Technical Training Department PT. ABC which has the responsibility for managing a training program in order to fit the company business needs, regulatory requirements, and the quality management system is necessary to conduct an evaluation analysis of production technician satisfaction towards training service quality which given to the entire production technician of production area PT. ABC. The analysis is conducted in order to define what factor that needs to be rectified by the department of technical training in the training process with respect to improving the quality of the training service.

\section{Methods}

\subsection{Service Quality}

Service quality method is a method that will be used to identify five gaps that may affect consumer towards evaluation of service quality. Dimensions of service quality in the Servqual based on the multi-items scales that are designed to measure customer expectations and perceptions as well as the gap between them in the service quality dimensions was originally by Parasuraman identified five principal dimensions related to the servicing and those dimensions are tangibles, reliability, responsiveness, assurance and empathy

\subsection{Importance Performance Analysis}

Importance Performance Analysis consists of two components, quadrant analysis and gap analysis. By using the quadrant analysis it can know the consumer response to the attributes that are plotted in order of importance of actual performance and expectation performance of the attribute. While the gap analysis was used to look at the gap between the actual performances to consumer expectations performance for the attribute, Cartesian diagram that used in this research is describing the level of expectation values and the perceived level of customer value.

\subsection{Sampling}

Sample considered as a representative of the population and the result is a representative of the overall phenomenon observed. Sampling was collected by purposive sampling method because the sample selected based on certain considerations relevantly or it can be represent the object of the research, the sampling was determined using Slovin's sampling table

\subsection{Validity Test}

Validity test is the test which conducted in order to measure of how closely a test (measuring tool) performs the function of measuring. The general understanding of the validity of the items is that an item (question) can be said to be valid if it has a strong support to the total score. In other words, an item inquiry is said to have high validity if there is alignment scores (high correlation) against the total scores of items. Thus, testing the validity of these items is done by using Pearson Product Moment Correlation test.

\subsection{Reliability Test}

Reliability test is dealing with the problem of permanence results or if a change in the results of tests / instruments, but the changes are not considered meaningful. The objective of this test is all data value that include in reliability test should be greater than 0.7 as the requirement of reliable data.

\section{Result and Discussion}

\subsection{Questionnaire Design}


By developing the service quality method by Parasuraman into the questionnaire that have five generic dimensions or factors that can be used to measure the satisfaction of production technician towards service quality on the training program and is stated as follows;

1. Tangibles.

In tangible dimension, the factors that will be discussed are about the physical facilities, and training equipment.

2. Reliability

In reliability dimension the factors that will be discussed are about the instructor to perform the promised service dependably and accurately way.

3. Responsiveness.

In responsiveness dimension the factors that will be discussed are the willingness of the instructor to help the production technician and provide prompt service. In responsiveness dimension it will be discussed also about the courtesy of technical training department and their ability to inspire trust for the trainee

4. Assurance

In assurance dimension the factors that will be discussed are including credibility, security, competence of the trainer and training material.

5. Empathy

In empathy dimension the factors that will be discussed are including access, communication and understanding the trainee. In this dimension it is also discussed about technical training department caring and individualized attention from the trainer that the department of technical training provides to its trainee.

Table1. Dimension and Total Questions

\begin{tabular}{|c|c|c|c|c|}
\hline Question & No & Dimension & Score Scale & Total \\
\hline \multirow{5}{*}{$\begin{array}{c}\text { Actual } \\
\text { Performance }\end{array}$} & 1 & Tangibles & \multirow{5}{*}{$\begin{array}{l}\text { Likert Scale } 1-5 \text { starting } \\
\text { from not very good until } \\
\text { very good }\end{array}$} & 5 Questions \\
\hline & 2 & Reliability & & 5 Questions \\
\hline & 3 & Responsiveness & & 5 Questions \\
\hline & 4 & Assurance & & 5 Questions \\
\hline & 5 & Empathy & & 5 Questions \\
\hline \multirow{5}{*}{$\begin{array}{l}\text { Expectation } \\
\text { Performance }\end{array}$} & 1 & Tangibles & \multirow{5}{*}{$\begin{array}{l}\text { Likert Scale } 1-5 \text { starting } \\
\text { from very unimportant } \\
\text { until very important }\end{array}$} & 5 Questions \\
\hline & 2 & Reliability & & 5 Questions \\
\hline & 3 & Responsiveness & & 5 Questions \\
\hline & 4 & Assurance & & 5 Questions \\
\hline & 5 & Empathy & & 5 Questions \\
\hline
\end{tabular}

Table 2. Questionnaire Question of Each Dimension

\begin{tabular}{|c|c|c|c|}
\hline $\begin{array}{l}\text { Questionnai } \\
\text { re Type }\end{array}$ & Dimension & Number & Question \\
\hline \multirow{8}{*}{ 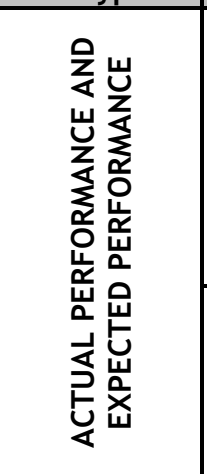 } & \multirow{5}{*}{ Tangibles } & 1 & $\begin{array}{l}\text { Physical appearance of training room has a modern design (size, } \\
\text { building amenities such as waiting room) }\end{array}$ \\
\hline & & 2 & The cleanliness of the training room are all concern \\
\hline & & 3 & $\begin{array}{l}\text { Toilets in the training room complete with the necessary amenities } \\
\text { (tissues, soap, etc.) }\end{array}$ \\
\hline & & 4 & Training room has a bright lighting \\
\hline & & 5 & Availability of air conditioner is well maintained \\
\hline & \multirow{3}{*}{ Reliability } & 6 & The training process started on time \\
\hline & & 7 & $\begin{array}{l}\text { The training materials in accordance with what is required by } \\
\text { production technician }\end{array}$ \\
\hline & & 8 & $\begin{array}{l}\text { The Instructor of the training is able to present the training materials } \\
\text { clearly }\end{array}$ \\
\hline & \multirow[t]{2}{*}{ Reliability } & 9 & $\begin{array}{l}\text { The contents of the training materials used to help production } \\
\text { technician in understanding the existing machines in the production } \\
\text { area }\end{array}$ \\
\hline & & 10 & $\begin{array}{l}\text { Evaluation test after training used to help Prodtect to reviewing the } \\
\text { materials learned during the training process }\end{array}$ \\
\hline
\end{tabular}


Table 3. Questionnaire Question of Each Dimension (continued)

\begin{tabular}{|c|c|c|c|}
\hline $\begin{array}{l}\text { Questionnai } \\
\text { re Type }\end{array}$ & Dimension & Number & Question \\
\hline \multirow{15}{*}{ 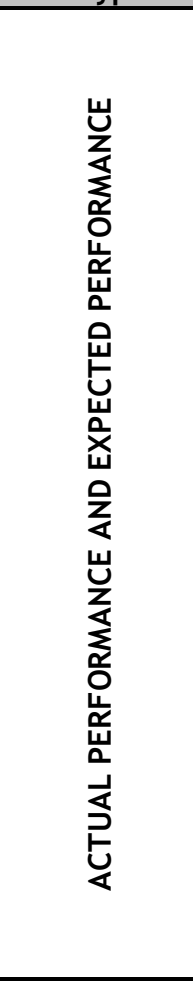 } & \multirow{5}{*}{$\begin{array}{l}\text { Responsiven } \\
\text { ess }\end{array}$} & 11 & $\begin{array}{l}\text { Instructors can easily be reached by production technician if there is } \\
\text { any training information that needs to be asked }\end{array}$ \\
\hline & & 12 & Instructor training being friendly during the training process \\
\hline & & 13 & $\begin{array}{l}\text { Instructor training did a quick response in handling questions from } \\
\text { training participants }\end{array}$ \\
\hline & & 14 & Instructor training be disciplined during the training process \\
\hline & & 15 & $\begin{array}{l}\text { All the Information for training is given approximately one week } \\
\text { before the training conducted }\end{array}$ \\
\hline & \multirow{5}{*}{ Assurance } & 16 & $\begin{array}{l}\text { Training Module is given to help production technician to understand } \\
\text { the material during the training process }\end{array}$ \\
\hline & & 17 & Production technician can undertake retraining if necessary \\
\hline & & 18 & $\begin{array}{l}\text { Production technician can ask the training materials back to the } \\
\text { instructor after the training process completed }\end{array}$ \\
\hline & & 19 & $\begin{array}{l}\text { If production technician missing the training module, they will be } \\
\text { given the new module }\end{array}$ \\
\hline & & 20 & Trainer show their professional attitude during training process \\
\hline & \multirow{5}{*}{ Empathy } & 21 & The ability of the instructor training in communicating with trainees \\
\hline & & 22 & Clear information of the schedule of the training \\
\hline & & 23 & Clear information of the training Regulation \\
\hline & & 24 & $\begin{array}{l}\text { Clear information about the training kit received by participant during } \\
\text { the training process }\end{array}$ \\
\hline & & 25 & $\begin{array}{l}\text { The training program information given to helps the readiness of } \\
\text { participants during the training process }\end{array}$ \\
\hline
\end{tabular}

\subsection{Training Participant Target}

The participants of the training are production technician from Maker, Packer and Filter area of secondary processing area PT. ABC with the total target participants 50 people. According to the annual report of technical training department, the number of training participants decreasing steadily since 2014 to 2015, the specific problem due to this research is especially look on training participants' targets that decreasing started from 2014 until 2015, the target of training participant and actual participant can be found in the table below.

Table 3. Training Participant Target

\begin{tabular}{|c|c|c|c|c|c|}
\hline \multirow[b]{2}{*}{ TRAINING NAME } & \multicolumn{4}{|c|}{ TOTAL PARTICIPANTS } & \multirow[b]{2}{*}{$\begin{array}{c}\text { TARGET } \\
\text { PARTICIPANTS }\end{array}$} \\
\hline & 2015 & $\begin{array}{c}2015 \\
\text { PERCENTAGE }\end{array}$ & 2014 & $\begin{array}{c}2014 \\
\text { PERCENTAGE }\end{array}$ & \\
\hline TRAINING MESIN GDX6 & 44 & $88.00 \%$ & 48 & $96.00 \%$ & 50 \\
\hline TRAINING LASER 600S & 44 & $88.00 \%$ & 47 & $94.00 \%$ & 50 \\
\hline TRAINING C800BV & 45 & $90.00 \%$ & 47 & $94.00 \%$ & 50 \\
\hline $\begin{array}{l}\text { TRAINING LASER } \\
\text { PERFORATOR }\end{array}$ & 45 & $90.00 \%$ & 48 & $96.00 \%$ & 50 \\
\hline \multicolumn{2}{|c|}{ AVERAGE PERCENTAGE } & $89.00 \%$ & & $95.00 \%$ & \\
\hline
\end{tabular}

\subsection{Determining Sample Size}

Based on these data, the total sample is shown by the equation by using Slovin's formula 2.1 from the journal by Jeffry J. Tejada and Joyce Raymond B. Punzalan with the title On the Misuse of Slovin's, as follows:

$$
\begin{aligned}
& n=\frac{N}{1+N(e)^{2}} \\
& n=\frac{50}{1+50(0.05)^{2}}=\frac{50}{1+50(0.0025)}=\frac{50}{1.125}=44.4 \text { rounded up to } 44
\end{aligned}
$$


Total Sample $=44$ Sample

Based on the calculation above, the sample obtained is 44 samples. The number of samples that have been known will be divided into three according to the area, which are Filter, Maker and Packer.

$$
\begin{array}{lll}
\text { Sample } 1 & = & \frac{\text { Population }}{\text { Total Population }} \times \text { Total Sample } \\
\text { Filter Area } & = & \frac{15}{50} \times 44=13.2 \text { rounded up to } 13 \\
\text { Maker } & = & \frac{20}{50} \times 44=17.6 \text { rounded up to } 18 \\
\text { Packer } & = & \frac{15}{50} \times 44=13.2 \text { rounded up to } 13
\end{array}
$$

Table 4. Research Sample based on Slovin Formula

\begin{tabular}{|l|c|c|}
\hline Area & Population & Proportion 5\% \\
\hline Filter & 15 & 13 \\
\hline Maker & 20 & 18 \\
\hline Packer & 15 & 13 \\
\hline Total & $\mathbf{5 0}$ & $\mathbf{4 4}$ \\
\hline
\end{tabular}

\subsection{Validity Test for Actual Performance Questionnaire}

Based on the table of $r$ values of product moment, the $r$ - table for $N=44$ with level of significance is 0.05 is 0.297 . If the questions have Pearson Correlation $r_{x y} \geq 0.297$ then the questions is valid. But when the questions have Pearson Correlation $r_{x y} \leq 0.297$ then the questions is declared invalid. If the questions are not valid, then the questions must be removed and re-tested in accordance with the procedure that has been done before in order to obtain valid result. Based on the calculations in the table above regarding production technician training service quality satisfaction questionnaire actual where the value of $r_{x y}$ compared with $r$ - table with the total sample 44 respondents and the percentage of error tolerance is $5 \%$ it obtained $r_{x y}$ larger than $r$ table for each question item of the questionnaire. So that, it can be concluded that each question item of production technician training toward quality satisfaction questionnaire actual is valid.

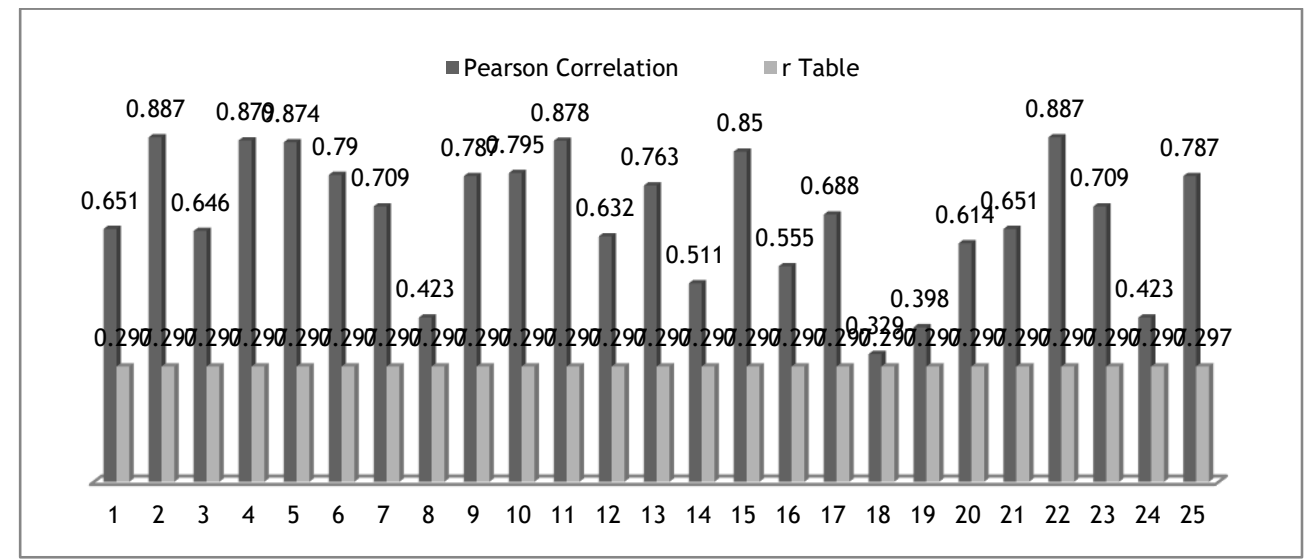

Figure 1. Validity Test for Actual Performance Result

\subsection{Validity Test for Expected Performance Questionnaire}

The calculations in the chart above regarding production technician satisfaction training service quality questionnaire expectation, the value of $r_{x y}$ compared with $r$ - table with the total sample 44 respondents and the percentage of error tolerance is $5 \%$ it obtained $r_{x y}$ larger than $r$-table for each question item of the questionnaire. So that, it can be concluded that each question item the questionnaire expectation is valid. 


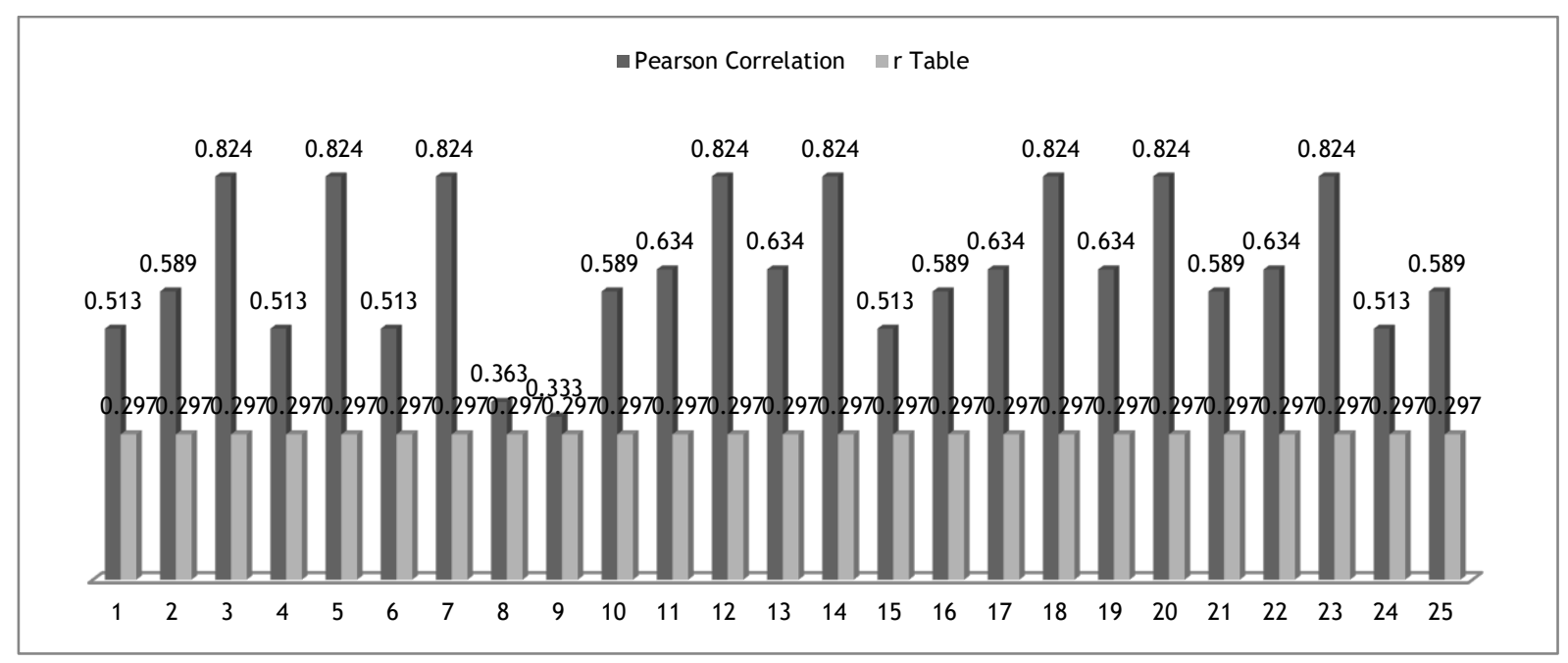

Figure 2. Validity Test for Expectation Performance Result

\subsection{Reliability Test of the Questionnaire}

Based on the data shown in the table above, the value of Cronbach's Alpha $r_{x y}$ for each question indicators of the actual performance and expectation performance is greater than $r$ - table $(0.297)$ for the total sample of 44 respondents with an error tolerance is $5 \%$. Reliability testing is done by comparing the value of the Cronbach's Alpha with the value of the Cronbach's Alpha if item deleted. If Alpha is low, the possibilities of one or several items are not reliable and should be conducted further tests to see certain items that are not reliable. Reliability test results with values of Cronbach's Alpha $>0.9=$ Reliable, Nunnally (1978) on the journal Validity and Reliability in Social Science Research by Ellen A. Crost on the Journal Education Research and Perspective recommends that a reliability of at least .90 will be desirable. The result shows that the question indicator is reliable and it can be used as data retrieval in the research.

Table 5. Reliability Test Result

\begin{tabular}{|c|c|c|c|c|c|}
\hline Question & No & Indicator & $\begin{array}{l}\text { Cronbach's } \\
\text { Alpha }\end{array}$ & $\begin{array}{c}\text { Reliability } \\
\text { Value }\end{array}$ & Result \\
\hline \multirow{5}{*}{$\begin{array}{l}\text { Actual } \\
\text { Performance }\end{array}$} & 1 & Tangibles & \multirow{5}{*}{0.953775} & \multirow{5}{*}{0.9} & \multirow{5}{*}{ Reliable } \\
\hline & 2 & Reliability & & & \\
\hline & 3 & Responsiveness & & & \\
\hline & 4 & Assurance & & & \\
\hline & 5 & Empathy & & & \\
\hline \multirow{5}{*}{$\begin{array}{l}\text { Expectation } \\
\text { Performance }\end{array}$} & 1 & Tangibles & \multirow{5}{*}{0.939374} & \multirow{5}{*}{0.9} & \multirow{5}{*}{ Reliable } \\
\hline & 2 & Reliability & & & \\
\hline & 3 & Responsiveness & & & \\
\hline & 4 & Assurance & & & \\
\hline & 5 & Empathy & & & \\
\hline
\end{tabular}

\subsection{Assessment from Production Technician towards Actual Performance and Expecting Performance}

Each of the questions that came from each dimension has a different gap. The table below shows the gap of each of the questions between actual performance and expecting performance from all of the aspect 


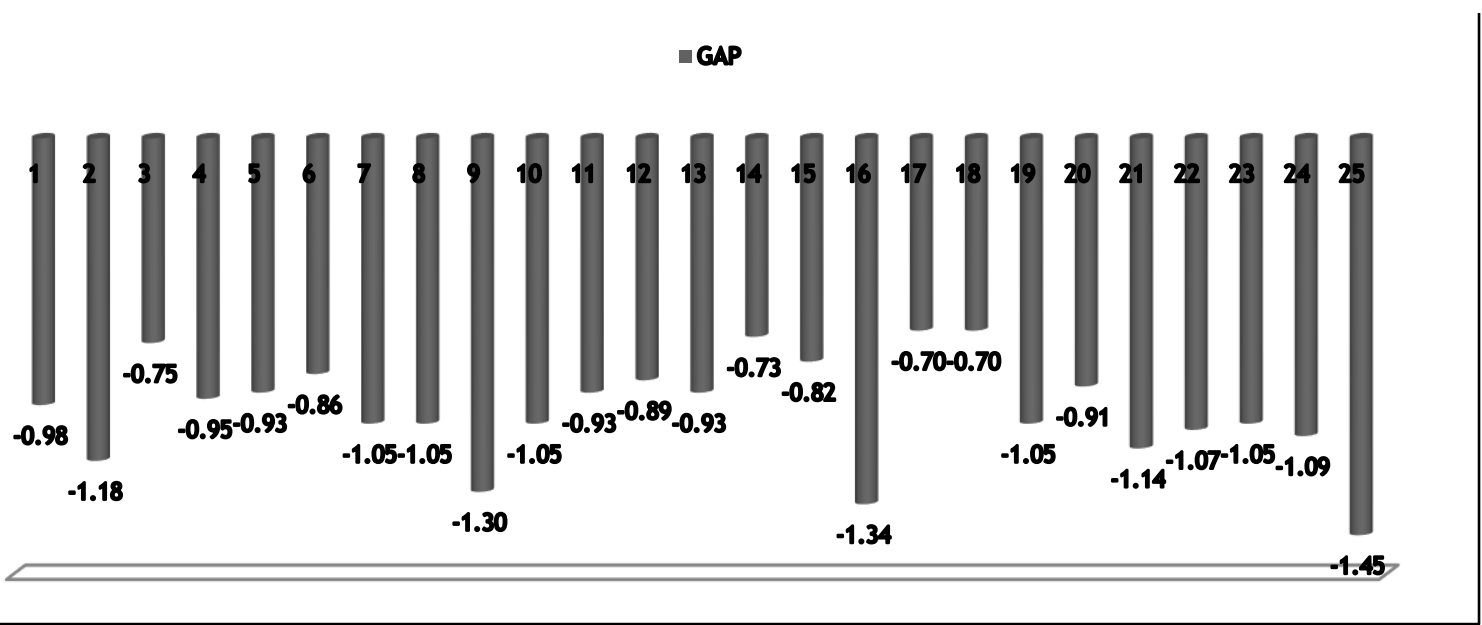

Figure 3. Gap Result of Actual Performance and Expectation Performance

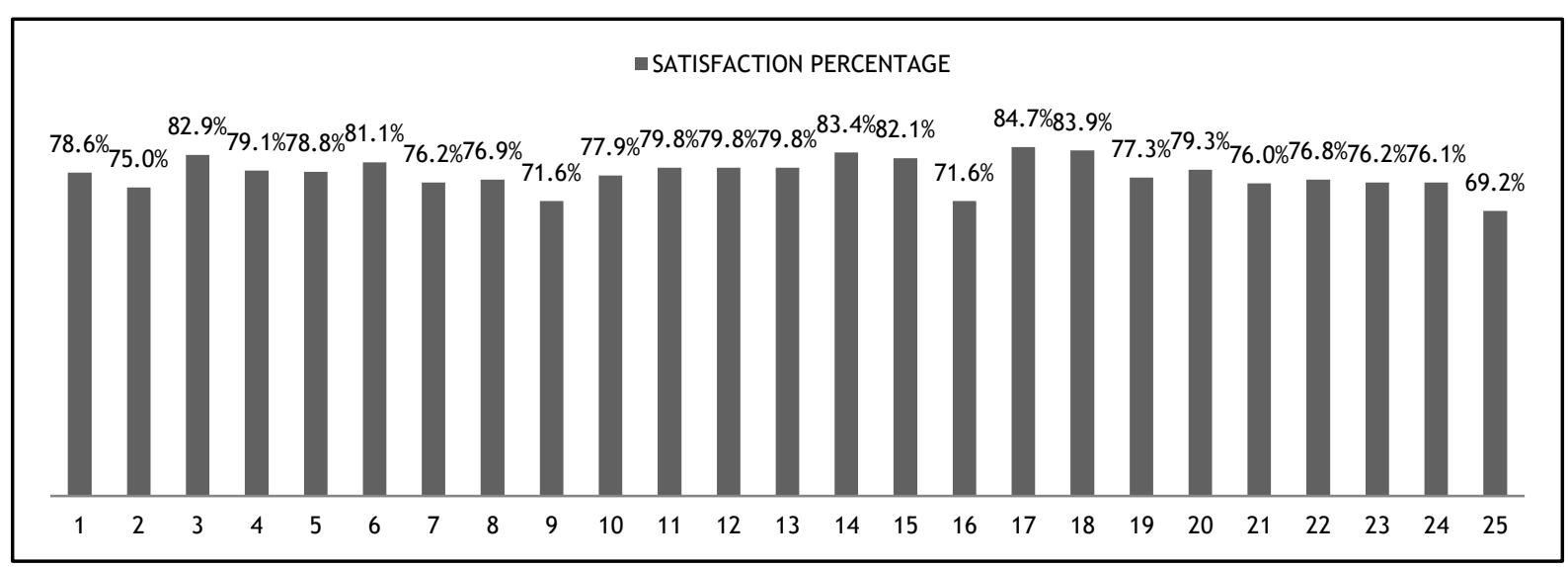

Figure 4. Satisfaction Percentage Result of Production Technician towards Training Service Quality

\subsection{Highest Satisfaction Percentage of Each Dimension}

Based on chart of satisfaction percentage of the highest percentage on each dimension it is shown that from the tangibles dimension the highest percentage is $82.9 \%$, from reliability dimension the highest percentage is $81.4 \%$, from responsiveness dimension the highest percentage is $83.4 \%$, from assurance dimension the highest percentage is $71.6 \%$ and the highest percentage on empathy dimension is $76.8 \%$.

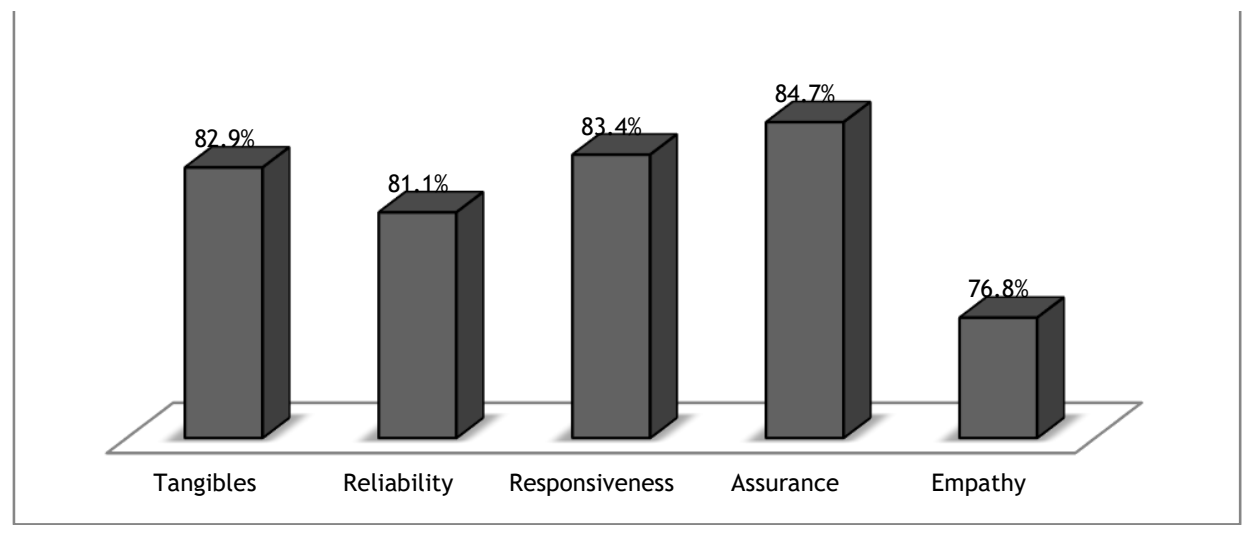

Figure 5. Highest Satisfaction Percentage of Each Dimension 


\subsection{Smallest Satisfaction Percentage of Each Dimension}

Based on chart of satisfaction percentage of the lowest percentage on each dimension it is shown that from the tangibles dimension the lowest percentage is $75 \%$, from reliability dimension the lowest percentage is $71.6 \%$, from responsiveness dimension the lowest percentage is $79.8 \%$, from assurance dimension the lowest percentage is $71.6 \%$ and the lowest percentage on empathy dimension is $69.2 \%$.

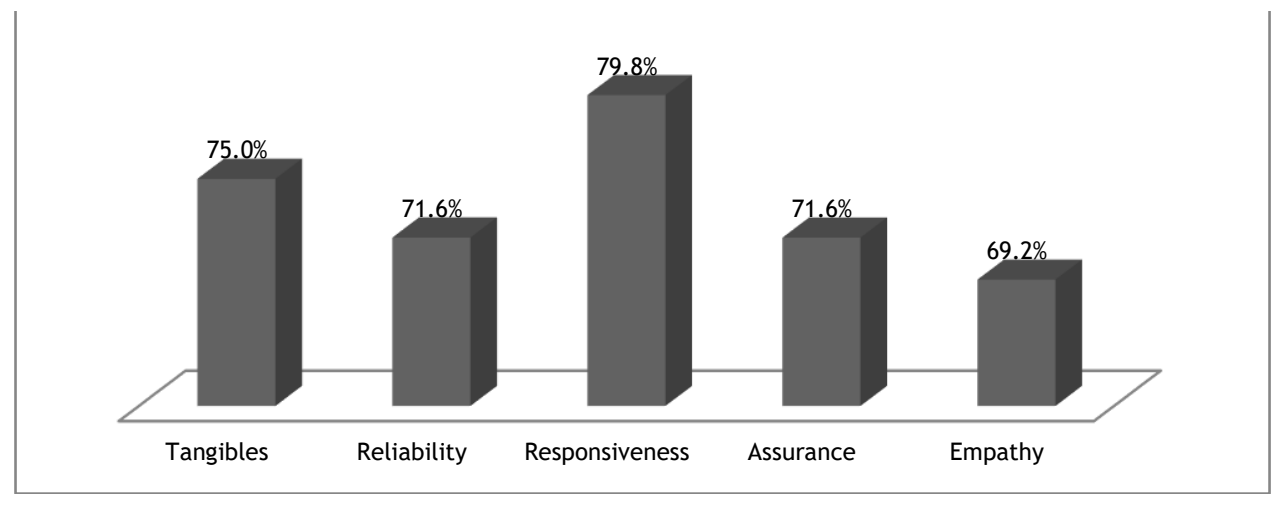

Figure 6. Lowest Satisfaction Percentage of Each Dimension

\subsection{Analysis of Training Participant Satisfaction Based on Service Quality}

In accordance to improve the training quality service, hence it is necessary to make a quadrant mapping to determine the priority scales repairs. The mapping is done by using the Cartesian diagram, where $X$ is the actual performance axis and $Y$-axis is the expectation performance.

In the previous analysis there are results for expectation performance and actual performance of training service quality from each dimension of Service Quality. As can be viewed, the gap of the actual value and expectation value is not very significant. The average satisfaction percentage of customer satisfaction based on actual performance and expectations performance is $78.20 \%$.

The actual value and the expectation value of a production technician is drawn into the Cartesian diagram in order to analyze any variable services that go into quadrant A which means that the variable becomes a priority for repair and need to be improved, Quadrant $B$ is a variable that will be a variable that has a performance that should be preserved, Quadrant $C$ is a variable with lower priority for repaired and Quadrant D means that the service is more than enough and even categorized as an excessive .

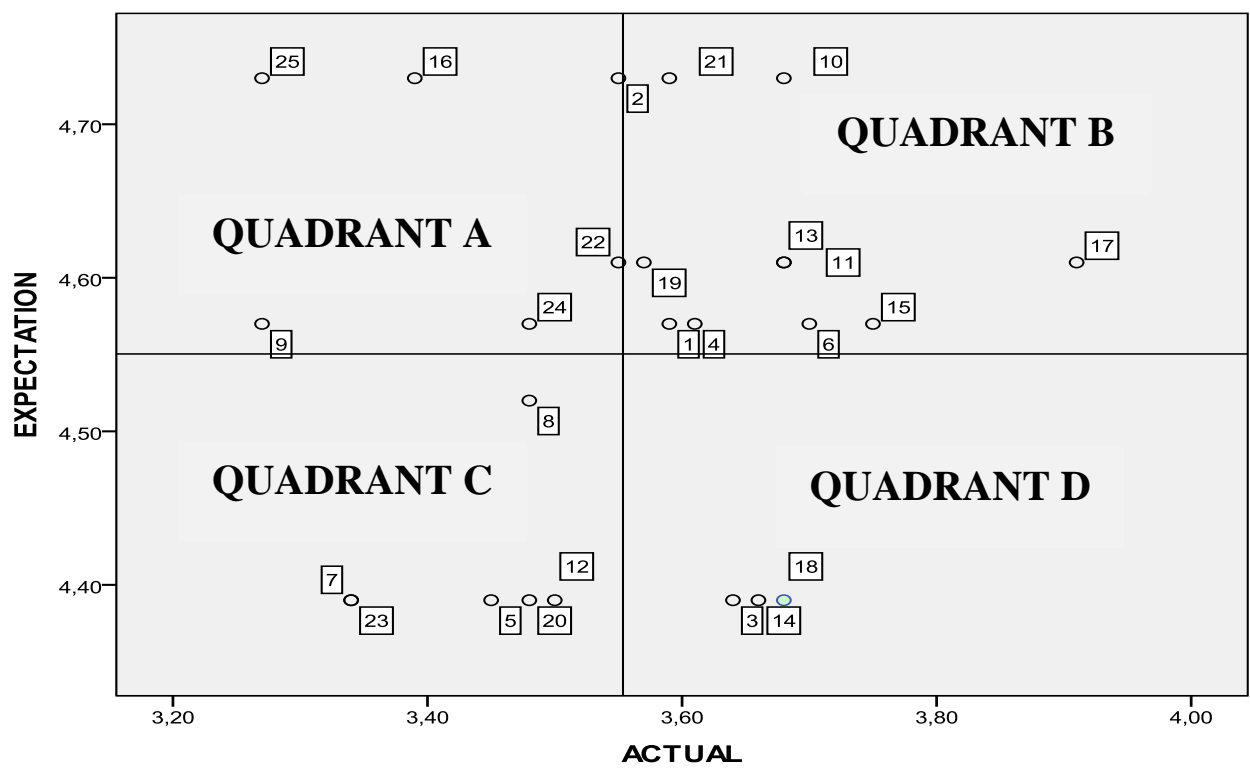

Figure 7. Cartesians Diagram of Importance Performance Analysis 


\subsection{Analysis Importance Performance Matrix}

Based on Cartesian quadrant, the interpretation of each quadrant will be described as follows;

\section{A. Quadrant A}

Attributes in quadrant A shows the factors which considered have an impact on production technician satisfaction towards quality of training service and it is considered important, but the department of technical training has not done the training in accordance with the expectation of the training participants and it caused training participants not satisfied with the services that already provided. The factors that included in quadrant A is as follows;

- (2) The cleanliness of the training room are all concerned

- (9) The contents of the training materials used to help production technician in understanding the existing machines in the production area

- (16) Training Module is given to help production technician to understand the material during the training process

- (22) Clear information of the schedule of the training

- (24) Clear information about the training kit received by participant during the training process

- (25) The training program information given to helps the readiness of participants during the training process

\section{B. Quadrant B}

Attributes in quadrant B are considered as an important and expected attributes and as a supporting factor for the satisfaction of training participants. Therefore, technical training department is obliged to ensure that the performance that has been managed by technical training department can continue to maintain the achievements that have been achieved. Quadrant B shows the factors that should be retained due to the performance demands of participants are relatively satisfied by the existing performance. The factors that included in the quadrant $B$ is as follows;

- (1) Physical appearance of training room has a modern design (size, building amenities such as waiting room)

- (4) Training room has a bright lighting

- (6) The training process started on time

- (10) Evaluation test after training used to help Prodtect to reviewing the materials learned during the training process

- (11) Instructors can easily be reached by production technician if there is any training information that needs to be asked

- (13) Instructor training did a quick response in handling questions from training participants

- (15) All the Information for training is given approximately one week before the training conducted

- (17) Production technician can undertake retraining if necessary

- (19) If production technician missing the training module, they will be given the new module

- (21) The ability of the instructor training in communicating with trainees

\section{Quadrant C}

This quadrant is categorized low on the level of achievement or the actual performance. The factor in this quadrant considered as the factor that not too important to be improved. Therefore, technical training department does not need to prioritize the factor in this quadrant to be repaired. The factors in Quadrant C indicate that the demand of the participant is not too high and the actual performance of technical training department has been able to meet these demands based on training participants need. The factors that included in this quadrant are as follows;

- (5) Availability of air conditioner is well maintained

- (7) The training materials in accordance with what is required by production technician

- (8) The Instructor of the training is able to present the training materials clearly

- (12) Instructor training being friendly during the training process

- (23) Clear information of the training Regulation 


\section{Quadrant D}

The factors that exist in this quadrant are factors that are considered less important by production technician and the actual performance is too exaggerated, so technical training department does not need to make an improvement for the factors that exist in this quadrant. Quadrant $D$ shows the factors based on actual performance perceived excessive because of the demands and expectations of the training participants actually is not high. The factors that included in this quadrant are as follows;

- (3) Toilets in the training room complete with the necessary amenities (tissues, soap, etc.)

- (14) Instructor training be disciplined during the training process

- (18) Production technician can ask the training materials back to the instructor after the training process completed

\section{Conclusion}

Based on the results of the data calculation and analysis, it can be concluded that;

1. Out of all the indicators with the total 25 indicators, it is obtained the gap from all of the items indicators with the negative values and the smallest gap is -0.70 and the largest gap is -1.45 . It gives an indication that the production technician has not satisfied with the quality of training service that conducted by the department of technical training.

2. Based on the results of calculations and analysis that has been done by using service quality method, an indicator that has the highest gap and can be categorized as a factor that affecting the satisfaction of training participants is the indicator number 25 which stated " The training program information given to helps the readiness of participants during the training process " with the total gap between the actual performance and the expectation performance is -1.45 with satisfaction percentage $69.2 \%$. If the analysis viewed is based on five dimensions, tangibles dimension, reliability dimension, responsiveness dimension, assurance dimension and empathy dimension, the dimension that has the lowest percentage of satisfaction is the dimension of empathy with satisfaction percentage amounted to $74.86 \%$ which explained about the clarity of training schedule and training regulations

3. Based on the analysis by using importance performance analysis method to the entire gap that appeared on 25 indicators, there are six factors that should be a priority by technical training department for the performance improvement to reduce the gap that occurs. The indicators are;

a. The cleanliness of the training room are all concerned

b. The contents of the training materials used to help production technician in understanding the existing machines in the production area.

c. Training Module is given to help production technician to understand the material during the training process.

d. Clear information of the schedule of the training

e. Clear information about the training kit received by participant during the training process.

f. The training program information given to helps the readiness of participants during the training process

\section{References}

1. Aditya Setyawan, Dodiet (2004). Modul Statistika Uji Validitas dan Reliabilitas Instrumen Penelitian, Surakarta.

2. Kulkarni, P and Pallavi (2014). A Literature Review on Training and Development and Quality of Work Life, Journal of Arts, Science \& Commerce. Vol. 4, No 2, pp. 136.

3. Obisi, Chris. (2011). Employee Training and Development in Nigerian Organization's, Some Observations and Agenda for Research, Australian Journal of Business and Management Research, Vol. 1, No. 9, pp. 82-91.

4. Parasuraman, A. Zeithmal, A. and Berry, L. (1998) SERVQUAL; a multi-item scale for measuring consumer perceptions of the service quality, Journal of Retailing, Vol. 64, No. 1, pp. 12-40. 
5. Parasuraman, A. Zeithmal, V. and Berry, L. (1998). A Conceptual Model of Service Quality and Its Implication for Future Research, Journal of Marketing, pp. 41-50.

6. Tejada, Jeffry J. and B, Punzalan. Joyce, Raymond. (2012). On the Misuse of Slovin's Formula, The Philippine Statistician Journal, Vol. 61, No. 1.

7. Yuvina Tileng, Marlin. Herry Utomo, Wiranto and Latuperissa, Rudi. (2013). Analysis of Service Quality using Servqual Method and Importance Performance Analysis (IPA) in Population Department, Tomohon City, International Journal of Computer Applications, Vol. 70, No. 19. 